\title{
Methods of Conflict Study in the System of Education
}

\author{
Marina V. Rostovtseva* and Aleksandr A. Mashanov \\ Siberian Federal University \\ Krasnoyarsk, Russian Federation
}

Received 19.01.2020, received in revised form 21.01.2020, accepted 12.02.2020

\begin{abstract}
The article raises the problem of developing methods for studying conflicts in the education system. The definition of conflict is given as a process that actualises violations by the subjects of interaction of established norms, rules, laws, requirements of a particular social environment. It is emphasised that today there are two main methodological approaches to the study of conflicts: activity-oriented and personalityoriented. The activity-oriented paradigm considers conflicts from the point of view of activity and development of the subjects of interaction and social environment. The personality-oriented approach focuses on the importance of personal characteristics of the interacting parties to resolve a conflict situation. The authors propose a comprehensive approach based on the symbiosis of personality-oriented and activity-oriented paradigms, which allows to take into account the main personal factors of subjects in the process of deployment and resolution of conflicts at each stage of a conflict situation: characterological peculiarities, self-esteem and intelligence, as well as behaviour strategies. An empirical pilot study was conducted among students of Siberian Federal University in order to determine leading personality features of an individual, which occupy the central place in a conflict, regardless of its stage and determine their relationship with the level of proneness to conflicts of a person.

The data obtained allowed us to come to preliminary conclusions that a low level of proneness to conflicts is associated with such qualities as high intelligence, ability to think outside the box, emotional stability, self-confidence and awareness of one's own capabilities. A high level of proneness to conflicts is due to the student's inability or unwillingness to understand and accept the individuality of other people, inability to forgive others for their mistakes, low intelligence, emotional instability and anxiety. The revealed relationships confirmed the effectiveness of using an integrated approach to the study of conflicts, as well as the theoretical assumption of the mutual influence of individual psychological characteristics and the level of proneness to conflicts of a person. The results of the study will allow us to investigate the mechanisms of conflict behaviour of learners, taking into account their individual psychological characteristics at each stage of the development of a conflict situation, and therefore manage conflicts in the education system.
\end{abstract}

(C) Siberian Federal University. All rights reserved

* Corresponding author E-mail address: marin-0880@mail.ru, aa-mashanov@yandex.ru 
Keywords: conflict, education system, research methodology, contradiction, activity approach, personal characteristics, behavior strategy, self-esteem.

Research area: social sciences.

Citation: Rostovtseva, M.V., Mashanov, A.A. (2020). Methods of conflict study in the system of education. J. Sib. Fed. Univ. Humanit. Soc. Sci., 13(2), 208-218. DOI: 10.17516/1997-13700552 .

\section{Introduction}

The relevance of the study of conflicts in the education system is associated with at least two key factors.

The first factor, which is topical at all times, can be designated as ontological, and here it is necessary to take into account social being, both globally and at the level of an individual, personality.

In this regard, conflict is relevant as a specific interaction strategy, which actualises at least two of its manifestations. The first is due to the fact that we can use the word "conflict" as a definite source of development, the driving force of social progress and human. Here we see it as something positive and necessary for social being and interaction. In the education system, conflict as a social phenomenon is inevitable, since this system cannot be stagnated and characterised by constants, and therefore, conflicts provide a person with the opportunity to realise and understand the changes that are taking place and see his or her place in the social structure (Antsupov, 2015). The conflict in these conditions appears as the embodiment of such a present in the education system, which is valuable for its affirmation of the future.

The second point is exactly the opposite and reflects the specificity of the modern social situation in the Russian education system, and therefore many learners perceive modern conflict as a negative phenomenon. The enthusiasm that embraced the entire system of Russian education in the early 2000 s has already declined, and today pessimistic moods prevail in society as a whole in relation to the ideals that the educational reform once showed us (Ermolaeva, 2016). The subjects of education and society as a whole are "tired" of looking for stability, order and some kind of consensus, and the endless changes that cause continuous shaking in the education system are already a priori accepted by many with hostility even before these changes are put into practice. It is no exaggeration to say that students, parents, teachers, and management personnel are those main subjects who, being in a "chronic" conflict with each other, feel the need to resolve it, and therefore methodological support and a research vector are needed that would enable to carry out prevention, effectively regulate and anticipate conflict situations.

The second factor is more specific. It is connected with the fact that development of methods for studying conflicts, especially with regard to the education system, is relevant in the context of understanding conflicts as a strategy for interaction at each stage of training and education process in the educational environment. The educational environment is a combination of all types of purposeful personality formation, and its essence is the activity of transferring and mastering social experience (Davletshina, Melnik, 2016). Therefore, favourable socio-psychological conditions are needed here that provide psychological comfort to teachers, students and parents (Acar et al., 2018). It is no coincidence that many modern scholars have shown growing interest in mediation as one of the effective forms of pre-trial settlement of disputes in the education system (Smolyaninova, Popova, 2019).

In any case, today a holistic methodological system is needed that would allow us to investigate, and subsequently effectively resolve conflict situations of various kinds between subjects of education. This article is devoted to a greater degree to the solution of the last problem. 
In any case, today a holistic methodological system is needed that would allow us to investigate, and subsequently effectively resolve conflict situations of various kinds between subjects of education. This article is devoted to a greater degree to the solution of the latter.

\section{Theoretical framework}

Let us start our investigation with determining the concept of "conflict".

Analysing the existing literature, we have faced the fact that in many scientific sources the concepts: "conflict", "contradiction", "problem" are used as synonymous (Salminen et al., 2019). It seems to us that these are completely different concepts and the concept of conflict is a category that has its own specificity. In order to avoid compilation and not to redefine the terms that have been studied enough, let us give a brief outline of our own position.

In our opinion, contradiction is a ratio of opposing subjects, their properties, sides. Contradictions are objective and inevitable in our life, they are difficult to manage and impossible to avoid. We are talking not only, for example, about global cataclysms, but also about changes in objective reality at the private level (illness, genetic characteristics, etc.).

We consider problem to be a subjective attitude of a person to an objective contradiction. The problem is actualised by circumstances that are significant and important for a given subject, while for other subjects of the relationship, these circumstances may not be perceived as problematic.

In our opinion, conflict is an attitude of opposing parties, in which one or all parties violate the "rules" (norms, laws, principles, traditions), both formal and informal, accepted or established in a particular social environment. Conflict (if this is not an affectation) often involves both a contradiction and a problem, while a problem situation and a contradiction are not necessarily a conflict. At the same time, the opposite side must definitely notice this violation of the rules so that a conflict occurs. If a student is absent (violation of established rules), but his or her parents do not know about it, then there will be no conflict until this fact is revealed to them.
This position makes it obvious that methodological "units" of conflict measurement should be the largest possible number of significant links between conflict and its substructures and factors that determine its appearance. It is naturally impossible to fully investigate all such relationships, but the nature of main connections that need to be highlighted can be taken into account.

In our opinion, in modern literature two methodological approaches to the study of conflicts are clearly formed: activity-oriented and personality-oriented.

Considering conflicts in the context of the activity-oriented paradigm and one of its aspects - a systematic approach, conflict is understood as a complex system of relationships, which are carried by people and society. Conflict acts as a source of social development and makes it possible to obtain a deeper essential characteristic of man and society. However, conflicts themselves, in our opinion, cannot be called the reasons for the development of man and society. It is more correct to talk here not about the causes, but about the conditions for the emergence of conflicts, which, one way or another, come down to differences between interacting entities (Tehrani, Yamini, 2019). The presence of differences between the subjects of a conflict is a necessary condition for its occurrence. Differences cause conflicts, and conflicts already polarise and strengthen the differences of the interacting parties. The very emergence and resolution of conflicts is an activity, the result of which is the development of the subjects of the conflict (Voronina, 2017).

The majority of human conflicts from the point of view of the activity-oriented approach are associated with differences in ideas, capabilities, needs of the individual in relation to the characteristics of society, its requirements, norms, rules, laws. These are external conflicts characterised by a clear fixed polarity of interacting entities, their spatial separability. However, there are intrapersonal conflicts, when it is appropriate to talk not about the clash of opposites, but about the conflict of the subject with himself, about self-denial and self-contradiction of the subject. In this context, intrapersonal conflict can be defined as the essence of 
self-movement, self-development of the subject (Strebkov, Sunami, 2016).

In the higher education system, for example, a student very often encounters differences and a mismatch of their own characteristics with the characteristics and requirements of the educational environment. This can be expressed in the contradiction between their knowledge and the requirements of the university. The discovery of these external differences encourages the student to go deeper into his own inner world and seek answers to questions about the search for homeostasis with the educational environment.

Therefore, an external conflict stimulates the individual's internal struggle with himself/herself, motivates to introspection, self-reflection, mental and physical activity in the search for a solution to the problem. This is the main position of understanding the conflict from the point of view of the activity-oriented approach.

The second approach is personality-oriented (Zhi et al., 2019).

This approach is borrowed rather from psychological science and is formulated as the need to identify and take into account specific personality traits that are a system-forming characteristic that determines the essence of the conflict (Karpova, Zaichikova, 2016). It explores those key personality traits that have or can have a decisive influence on the occurrence of a conflict situation (Pervyakova, 2010).

Of course, supporters of this approach do not exclude that one of the main causes of conflict situations may be changes that occur in our environment objectively and independently from us. However, people, even in the same circumstances, behave in completely different ways (Motornaya, 2016). One way or another, according to the principle of S.L. Rubinstein, all external influences are refracted through the internal determinants of the subject of a conflict situation.

Any conflicts, whether global ones - wars, revolutions, interstate disputes - or those of a smaller scale are initiated by specific people with specific psychological characteristics. In this regard, even the causes of conflicts are difficult to understand without knowing what role specific individuals played in them (Orian Harel, Maoz, Halperin, 2019).

Thus, the methodology of a personality-oriented approach is based on knowing the types of conflict situations, the subjects of which are a specific person with their specific features, as well as on methods and techniques for studying various properties, qualities and other characteristics of a person in specific situations of interaction.

\section{Statement of the problem}

In our opinion, each of the described approaches has its own value and significance, however, the use of only one of them seems insufficient. A comprehensive methodological approach is needed that combines the understanding of a conflict as a source of movement and development, as a process that has its own stages, at each of which significant personal characteristics appear that must be taken into account in order to effectively manage a conflict situation. A similar integrated approach to the education system can be described as follows.

Conflict is one of the "classical" strategies of interaction between people (Pustovalova, 2016; Hirvonen, 2019). It has its beginning, continuation and completeness, that is, certain stages. Therefore, borrowing the methodology of the activity-oriented approach, its specificity can be studied at each stage of development: from the initial stage - the onset of a conflict when it is still in a potential state; activation stages - when the potential becomes actual and there is a clear "violation of the rules" by one or all participants involved, and the final stage when the result of the conflict interaction is clearly visible, which needs to be assessed.

Moreover, at each of the described stages, it is necessary to monitor the personality and peculiarities of a person's behaviour in a conflict, borrowing the methodology of the personality-oriented approach (Pai, Bendersky, 2019).

These peculiarities, in our opinion, reveal themselves through interpersonal interaction of the subjects in a conflict situation. These include characterological features (manifestation of a relationship to another), self-esteem 
(attitude to oneself) and intelligence, as well as strategies for behaviour in conflict situations.

Since conflicts in education are actualised in the interaction of subjects of education, namely in communication, the sphere of communication becomes a leading sphere that can be studied and described to understand the entire conflict situation as a whole (Grishina, 2008).

In this regard, we can distinguish the main conflict situations that arise at the level of communication in the educational environment, which can be updated on cognitive (understanding of meanings), emotional (ability to empathy, tolerance, acceptance and understanding of the psycho-emotional characteristics of another person) and activity (the ability to effectively and efficiently carry out core activities, the ability to prevent and resolve conflicts) levels. Violations at any of these levels can lead to conflict situations, which means a decrease in overall performance indicators and the quality of training in the educational system.

Therefore, prevention of conflicts and search for effective ways of resolving them in the educational environment can be based on the methodology of the proposed integrated approach, which involves considering and understanding conflict as a process that has its own stages (generation, activation and completion), each of which reveal leading personality traits of an individual that determine the content and specificity of these stages. This position combines the activity-oriented and personally-oriented approaches and allows us to consider conflict as a process that has meaningful specificity at each stage of its development.

Personality traits of an individual at the stage of the onset of conflict have their own characteristics associated with the subject's initial assessment of the conflict situation, the search for his own internal capabilities and reserves for its resolution. At the stage of conflict intensification, the strategies of behaviour that the subject chooses in order to resolve the conflict will come to the fore. Finally, at the final stage, it is important to consider those personality features that are associated with the individual's overall assessment of the conflict situ- ation, self-esteem, level of satisfaction with the outcome of the resolution (its absence) of the conflict, and potential intentions and attitudes towards similar situations, if they occur.

\section{Methods}

To test the proposed integrated approach, we organised and conducted a study whose purpose was to diagnose the leading personality traits of the individual, which are the central link in the conflict, regardless of its stage and determine their relationship with the level of proneness to conflicts of a person.

The survey was conducted among firstyear students of the Law Institute of Siberian Federal University. In total, 135 people took part in the study.

An empirical study was carried out using the following methods: R. Cattell's 16-factor questionnaire, which is designed to measure sixteen personality factors and provides multifaceted information about personality traits called constitutional factors; test of behaviour description by K. Thomas, adapted by N.V. Grishina, to study personal predisposition to conflict behaviour; A. Sizanov's technique "Level of proneness to conflicts of a person"; A. Sizanov's test "Self-assessment of proneness to conflicts"; allowing to assess the degree of one's own proneness to conflicts.

\section{Discussion}

During the study, the following results were obtained:

According to K. Thomas's test describing behaviour, it was found that $20 \%$ of respondents seek to achieve satisfaction of their interests at the expense of another; $7 \%$ come to an alternative that fully meets the interests of both parties; 30\% seek a compromise in the current conflict situation; $23 \%$ lack a desire for cooperation and a tendency to achieve their own goals, and finally, $20 \%$ of respondents sacrifice their own interests for the interests of another (Fig. 1).

Analysing the data, it was concluded that most of the respondents seek a compromise in case of a conflict. A significant part of the respondents lacks the desire for cooperation and achievement of their own goals. A small per- 


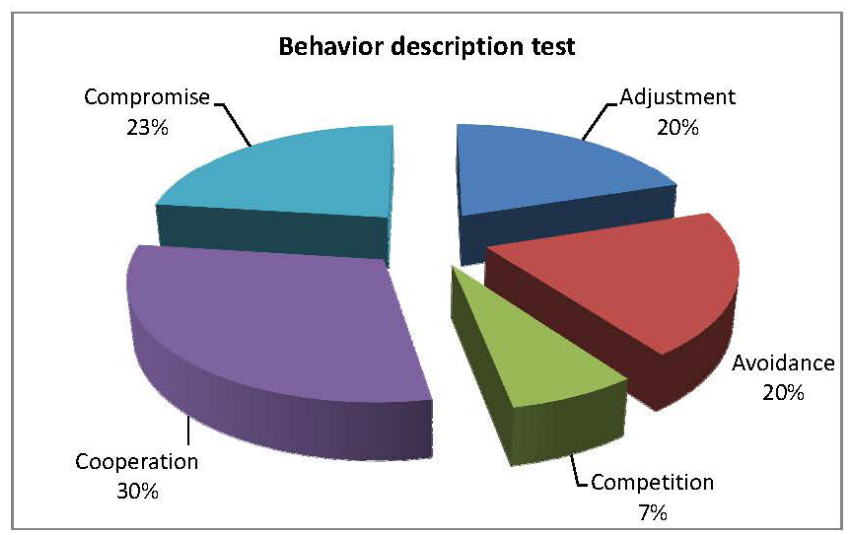

Fig. 1. Description of students' behaviour

Table 1. The level of proneness to conflicts of students.

\begin{tabular}{|l|c|}
\hline \multicolumn{1}{|c|}{ The level of proneness to conflicts } & \% from the amount of respondents \\
\hline Very high & $3.8 \%$ \\
\hline High & $19.2 \%$ \\
\hline Above average & $26.9 \%$ \\
\hline Slightly above average & $7.7 \%$ \\
\hline Average & $11.5 \%$ \\
\hline Slightly below average & $19.2 \%$ \\
\hline Below average & $3.8 \%$ \\
\hline Low & $3.8 \%$ \\
\hline Very low & $3.8 \%$ \\
\hline
\end{tabular}

centage of respondents who, in the event of a conflict, seek cooperation.

According to the A. Sizanov's method "The level of proneness to conflicts of a person", the results showed that the majority of respondents (26.9\%) had a very high level, $19.2 \%$ had a high level, and the same percentage of respondents had a level slightly lower than average. A low level of proneness to conflicts was determined for $3.8 \%$ of respondents (Table 1).

After analysing the results obtained by A. Sizanov's test "Self-assessment of proneness to conflicts", we got the following indicators: the same number of students $(7.7 \%$ each) have the level of proneness to conflicts that is above average, below average, and low. $3.8 \%$ of respondents demonstrated inad- equately high level of proneness to conflicts, high degree of conflict was shown by $23.1 \%$, average degree of conflict by $38.5 \%$ and inadequately low degree of conflict by $11.5 \%$ of respondents (Table 2).

According to Cattell's test (16PF-questionnaire), data processing was performed using qualitative and quantitative analyses. Raw scores were transferred to the walls, then the average value was calculated for each factor.

The results of the quantitative analysis of diagnostic data on personality traits according to Cattell's method are presented by average values on the analysed scales and are reflected in the form of an averaged personality profile (Fig. 2).

As a result of data processing, we see that respondents are characterised by average se- 
Table 2. Self-assessment of proneness to conflicts by students

\begin{tabular}{|l|c|}
\hline \multicolumn{1}{|c|}{ The level of proneness to conflicts } & $\%$ from the amount of respondents \\
\hline Inadequately high & $3.8 \%$ \\
\hline High & $23.1 \%$ \\
\hline Above average & $7.7 \%$ \\
\hline Average & $38.5 \%$ \\
\hline Below average & $7.7 \%$ \\
\hline Low & $7.7 \%$ \\
\hline Inadequately low & $11.5 \%$ \\
\hline
\end{tabular}

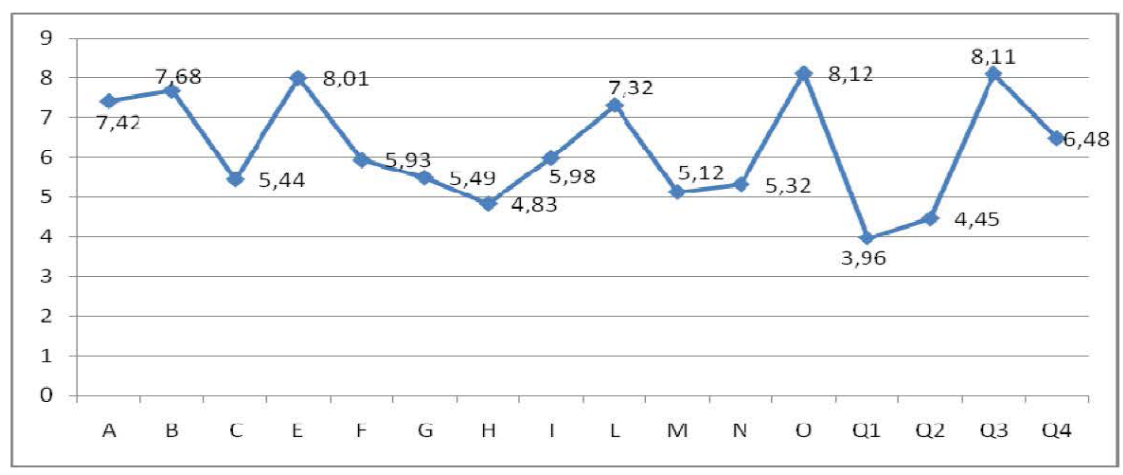

Fig. 2. Personal profile by average values

verity indicators on many scales (in scores) - C ("Emotional instability/Emotional stability" 5.55), F ("Equanimity/Impulsivity" - 5.93), G ("Self-serving/Conscientious" - 5.49), H ("Shyness/Courage" - 4.83), I ("Heartlessness/ Soft-heartedness" - 5.98), M ("Practicality/ Dreaminess" - 5.12), N ("Naivety/Insight" 5.12), Q2 ("Dependence on the group/Self-sufficiency" - 4.45).

High scores on the scales were identified by 7 factors - A ("Closure/Sociability" - 7.42), B ("Intelligence" - 7.68), E ("Subordination/ Dominance" - 8.01), L ("Credence/Suspicion" - 7.32), O ("Calmness/Anxiety" - 8.12), Q3 ("Low self-control/High self-control" 8.11), Q4 ("Relaxation/Tension" - 6.48).

Low scores on the scales were identified only by Q1 factor - "Conservatism/Radicalism" -3.96 points.

At the next stage of processing the obtained data, the task was to find out: what is the personality characteristic of a student with high and low levels of proneness to conflicts?
According to the correlation analysis, we found that a low level of proneness to conflicts is interconnected with such personal features as high intelligence $\left(\mathrm{B}-\mathrm{r}=0.731^{* *}\right)$, emotional stability $\left(\mathrm{C}-\mathrm{r}=0.598^{*}\right)$, suspiciousness $\left(\mathrm{L}-\mathrm{r}=-0.624^{*}\right)$, insight $\left(\mathrm{N}-\mathrm{r}=0.601^{* *}\right)$, tendency to guilt $\left(\mathrm{Q}_{4}-\mathrm{r}=-0.584^{* *}\right)$, radicalism $\left(\mathrm{Q}_{1}-\mathrm{r}=0.638^{* *}\right)$, the ability to restrain anxiety $\left(\mathrm{Q}_{3}-\mathrm{r}=0.596^{*}\right)$, anxiety $\left(\mathrm{O}-\mathrm{r}=-0.647^{* *}\right)$.

According to the correlation analysis, one can pre-compile a personality portrait of a student with high and low levels of proneness to conflicts.

A low level of proneness to conflicts is associated with such qualities as: high intelligence, ability to think outside the box, high ability to learn; emotional stability, adequate assessment of the situation, endurance; patience, adjustment, lack of desire for competition; sincerity, immediacy, emotionality; confidence in oneself and one's capabilities, vivacity, cheerfulness, insensitivity to approval or disapproval from others, vigour; tolerance 
for difficulties; sociability; control of one's emotions and behaviour, orderliness in work, determination, awareness and observance of social requirements.

A high level of proneness to conflicts is caused by inability or unwillingness of a student to understand and accept individuality of other people, desire to re-educate a partner, inability to forgive others for their mistakes, low intelligence, emotional instability, anxiety, suspiciousness.

\section{Results}

Thus, analysing the results of our study, we came to the conclusion that there is a relationship between the conflict and the individual psychological features of a person.

The results obtained indicate that the study expands the already existing ideas about the human factor in the conflict behaviour of an individual. The revealed correlations between individual psychological characteristics and personality conflict once again confirm the effectiveness of using an integrated approach to conflict research based on the symbiosis of an activity-oriented and personality-oriented paradigm, as well as a theoretical assumption about the influence of individual psychological characteristics on a conflict situation. These data allow us to study the mechanisms of conflict behaviour of an individual, taking into account their individual psychological characteristics at each stage of the development of a conflict situation in the educational system.

It is noteworthy and significant that $23.1 \%$ of respondents rate their own proneness to conflicts as high, while $30 \%$ choose a compromise strategy in the event of a conflict. We suggested that self-assessment of the level of conflict occurs at the initial stage of the emergence of a conflict situation, when a student only assesses his or her own capabilities for resolving it. When the conflict goes into the next phase of its development, the individual already in the real situation of the conflict begins to show a reasonable attitude towards it and chooses a compromise strategy.
Of course, the emergence of conflict situations in the educational system is due to a number of factors. This study is more likely a pilot one, and will certainly be expanded and continued in the future. We see the prospects for its development in an increase in the sample of respondents, the implementation of a more detailed and thorough correlation analysis and the links between all identified factors: characterological features (manifestation of attitude towards another), self-esteem (attitude towards oneself) and intelligence, as well as strategies for behaviour in a conflict situation.

Thus, the methodological programme for the study of conflict situations in the education system can be implicated by four key points:

1. Conflict is an interaction strategy in which one or all participants violate accepted formal and informal rules, laws, norms, requirements of a particular environment.

2. Explication of the conflict involves its study in the aggregate of pivotal factors and characteristics that are mediated by both mental and characterological features of the subjects, and objectively given circumstances or ongoing changes in a particular social environment.

3. The complex, multicomponent structure of the conflict necessitates the application of an integrated approach to its study, based on the symbiosis of an activity-oriented and personality-oriented paradigms. From this position, the conflict can be considered as a phased process, where each of the stages has its own specificity, due to the personal peculiarities of the subjects of the conflict, the leading of which are: characterological features, self-esteem and intelligence, as well as strategies for behaviour in a conflict situation.

4. The study of the personality peculiarities of an individual at each stage of a conflict situation will allow to precisely have the necessary effective impact on the subjects of the conflict, predict, adjust, prevent conflict, and manage it in specific conditions of life. 


\section{References}

Acar, I.H., Pérez-González, S.B., Kutaka, T.S., Yıldız, S.D. (2018). Difficult temperament and children's peer relations: the moderating role of quality of parent-child relationships. In Early Child Development and Care, 189, 2141-2155. DOI: 10.1080/03004430.2018.1439941

Antsupov, A.Ya. (2015). Konfliktologiia [Conflictology]. Moscow. Unity-Dana, 591.

Bjarnøe C., Vreese, C.H, Albæk, E. (2019). The effect of being conflict non-avoidant: linking conflict framing and political participation. In West European Politics, 43, 102-128. DOI: 10.1080/01402382.2 019.1572334

Davletshina, A.M, Melnik, N.B. (2016). Pedagogicheskii konflikt: filosovsko-pravovoi analiz [Pedagogical conflict: philosophical and legal analysis]. Ekaterinburg. In News of the Ural Federal University, 11 (2), (152)20-31.

Ermolaeva, E.G (2016). Vzaimosviaz vnutri lichnostnikh konfliktov studentov-psikhologov s ikh povedeniem $\mathrm{v}$ meshlichnostnikh konfliktakh [The relationship of intrapersonal conflicts of student psychologists with their behavior in interpersonal conflicts]. In Academic Journal of Western Siberia, 12 (2), (63) 47.

Grishina, N.V. (2008). Psihologiia konfliktov [Psychology of conflict]. 2nd ed. St. Petersburg, G85, 544.

Hirvonen, P. (2019). Positioning, conflict, and dialogue in management teams. In Qualitative Research in Organizations and Management: An International Journal, 14, 444-464. DOI: 10.1108/QROM05-2018-1637

Karpova, E.A., Zaichikova, I.B. (2016). Perespektivi ponimaniia konflikta v protsesse razvitiia proffesionalnoi identichnosti [Prospects for understanding conflict in the development of professional identity]. St. Petersburg. St. Petersburg University of Management Technologies and Economics, Sociology and Law, 3 (33), 64-76.

Kang, J.S. (2019). Ethics and Industry Interactions: Impact on Specialty Training, Clinical Practice, and Research, 46, 119-133. DOI: 10.1177/0306624X19842057

Motornaya, S.E. (2016). Isledovanie vliianiia urovnia kultury na vybor povedeniia v konflikte sovremennogo vupusknika [Study of the influence of the level of culture on the choice of behavior in the conflict of a modern university graduate]. In Azimuth of Scientific Research: Pedagogy and Psychology, 5 (16), 286-290.

Orian Harel, T., Maoz, I., Halperin, E. (2019). A conflict within a conflict: intragroup ideological polarization and intergroup intractable conflict. In Current Opinion in Behavioral Sciences, 34, 52-57. DOI: 10.1016/j.cobeha.2019.11.013

Pai, J., Bendersky, C. (2019). Team status conflict. In Current Opinion in Psychology, 33, 38-41. DOI: 10.1016/j.copsyc.2019.07.001

Pervyakova, S.A. (2010). Konflicti v obrazovatelnikh uchrezhdeniiakh. Prichini i osobenosti. Sovremenie gumanitarnie isledovaniia [Conflicts in educational institutions. Reasons and features. Modern humanitarian studies]. Moscow. OOO Sputnik+, 6 (37), 180-184.

Pustovalova, E.V. (2016). Comunikativnaia kultura razresheniia konflikta [Communicative culture of conflict resolution]. Barnaul. In Sociology in the modern world: science, education, creativity. Altai State University, 8(1), 103-106.

Salminen, J., Hopf, M., Chowdhury, S.A., Almerekhi, H., Jansen, B.J. (2019). A conflict within a conflict: intragroup ideological polarization and intergroup intractable conflict. In Human-centric Computing and Information Sciences, 10(1), 1. DOI: 10.1186/s13673-019-0205-6

Smolyaninova, O.G., Popova, Ju.V. (2019). Specific issues of training intercultural mediators for education in europe and Russia. In Journal of the Siberian Federal University. Series: Humanities, 12 (2), 247-260. DOI: 10.17516/1997-1370-0392

Strebkov, A.V., Sunami A.N. (2016). Mezhdisciplinarnaia paradigma analiza konflictov tsenostey [The interdisciplinary paradigm of value conflict analysis]. St. Petersburg. Fond razvitiia kondliktologii, 4, 48-66.

Tehrani, H.D., Yamini, S. (2019). Personality traits and conflict resolution styles: A meta-analysis. In Personality and Individual Differences, 157, 109794. DOI: 10.1016/j.paid.2019.109794 
Voronina, T.V. (2017). K voprosam vozniknoveniia i razresheniia konfliktov studentov [On issues of the emergence and resolution of student conflicts]. Saratov. OOO institute upravleniia i economicheskogo razvitiia, 2 (33), 1309-1312.

Zhi, H., Qi, J., Qian, T., Ren, R. (2019). Conflict analysis under one-vote veto based on approximate three-way concept lattice. In Information Sciences, 316-330. DOI: 10.1016/j.ins.2019.12.065

\title{
Методология исследования конфликтов в системе образования
}

\author{
М.В. Ростовцева, А.А. Машанов \\ Сибирский федеральный университет \\ Российская Федерация, Красноярск
}

\begin{abstract}
Аннотация. В статье поднимается проблема построения методологии исследования конфликтов в системе образования. Дается определение конфликта как процесса, который актуализирует нарушения субъектами взаимодействия установленных норм, правил, законов, требований конкретной социальной среды. Подчеркивается, что на сегодняшний день существуют два основных методологических подхода к исследованию конфликтов: деятельностный и личностно-ориентированный. Деятельностная парадигма рассматривает конфликт с точки зрения движения и развития субъектов взаимодействия и социальной среды. Личностно-ориентированный подход делает акцент на значимости личностных особенностей взаимодействующих сторон для разрешения конфликтной ситуации. Авторы предлагают комплексный подход, основанный на симбиозе личностноориентированной и деятельностной парадигмы, позволяющий учитывать в процессе развертывания и разрешения конфликтов основные личностные факторы субъектов на каждом из этапов конфликтной ситуации: характерологические особенности, самооценку и интеллект, а также стратегии поведения. Проведено пилотажное эмпирическое исследование среди учащихся Сибирского федерального университета с целью диагностики ведущих личностных характеристик индивида, которые выступают центральным звеном конфликта независимо от его этапа, и определения их связи с уровнем конфликтности личности.

Полученные данные позволили сделать предварительные выводы о том, что низкий уровень конфликтности связан с такими качествами, как: высокий интеллект, способность к нестандартному мышлению, эмоциональная устойчивость, уверенность в себе и своих возможностях. Высокий уровень конфликтности обусловлен неумением или нежеланием обучающегося понимать и принимать индивидуальность других людей, неумением прощать другому его ошибки, низким интеллектом, эмоциональной неустойчивостью, тревожностью. Выявленные взаимосвязи подтвердили эффективность использования комплексного подхода к исследованию конфликтов, а также теоретическое предположение о взаимовлиянии индивидуально-психологических особенностей и уровня конфликтности личности. Результаты исследования позволят изучать механизмы конфликтного поведения субъектов образования, учитывая их индивидуально-психологические особенности на каждом этапе развертывания конфликтной ситуации, а значит, управлять конфликтами в условиях образовательной системы.
\end{abstract}


Ключевые слова: конфликт, система образования, методология исследования, противоречие, деятельностный подход, личностные особенности, стратегии поведения, самооценка.

Научная специальность: 22.00.00 - социологические науки. 